\title{
Pembuatan Tabloid Dinamis oleh Bagian Humas Setda (Sekretariat Daerah) Kabupaten Ciamis
}

\author{
Deni Herdiansah ${ }^{1}$ dan Yanti Setianti ${ }^{2}$ \\ ${ }^{1,2}$ Universitas Padjadjaran
}

\begin{abstract}
ABSTRAK
Penulisan artikel ini bertujuan untuk mengetahui perencanaan, pelaksanaan dan evaluasi dari pengelolaan Tabloid Dinamis yang dilaksanakan oleh bagian Humas Sekretariat Daerah Kabupaten Ciamis. Metode penulisan yang digunakan adalah metode deskriptif dengan teknik pengumpulan data observasi, wawancara dan studi pustaka. Objek penelitian ini adalah Tabloid Dinamis. Tabloid Dinamis merupakan sebuah media komunikasi internal pemerintahan Kabupaten Ciamis untuk publiknya sebagai penyampai informasi pembangunan Kabupaten Ciamis. Proses pembuatan Tabloid Dinamis dibagi menjadi beberapa tahap, yaitu: tahap sebelum produksi Tabloid Dinamis meliputi perencanaan isi dan rubrikasi, pengumpulan informasi Tabloid Dinamis dan proses desain dan layout. Tahap produksi Tabloid Dinamis meliputi frequency, quantity dan proses percetakan Tabloid Dinamis. Tahapan setelah Produksi Tabloid Dinamis meliputi proses peliputan dan evaluasi. Kesimpulan dari penelitian ini adalah Humas Setda (Sekretariat Daerah) Kabupaten Ciamis dalam "Pengelolaan Tabloid Dinamis sudah melakukan tahapan-tahapan pengelolaan media dengan baik yaitu meliputi tahap sebelum produksi, tahap produksi dan tahap setelah produksi. Saran dalam penelitian ini adalah agar lebih efektif sebaiknya memanfaatkan keadaan yang ada seperti pada saat peliputan acara pasti ada protokoler atau staf dari bagian lain yang hadir, lebih baik bekerja sama dengan staf lain untuk proses peliputan sehingga berita tetap didapatkan meskipun tim peliput tidak ada di lokasi yang sama perlu dibuatnya rubrikasi yang pasti dan baik agar informasi yang disajikan dapat terpilah dan pembaca dapat mencerna dan mencari informasi dengan lebih baik.
\end{abstract}

Kata-kata Kunci: Hubungan masyarakat; informasi; komunikasi; pengelolaan; tabloid

\section{Management of Dinamis Tabloid by Public Relations Division Setda (Regional Secretariat) Ciamis Regency}

\begin{abstract}
Writing aims to know planning, implementation and evaluation of the management of Dinamis Tabloid implemented by the public relations department of Regional Secretariat (Setda) Ciamis Regency. Writing method used is descriptive writing method with data collection technique that is observation, interview and literature study. With the object of research that is Dinamis Tabloid.Tabloid Dinamis is an internal communication media of Ciamis regency government for its public as conveyor information development of Ciamis Regency. The process of making Dynamic Tabloid is divided into several stages namely preproduction stage Dynamic Tabloid includes planning contents and rubrication, information gathering Dynamic Tabloid and design and layout process. Stages of Dynamic Tabloid production include frequency, quantity and dynamic tabloid printing process. Post-Production Stages Dynamic tabloids include the process of coverage and evaluation. The conclusion of this research is PR Setda (Regional Secretariat) Ciamis Regency in "Management of Dynamic Tabloid have done stages of media management well by that is covering stage of preproduction, production stage and stage of Post Production. The suggestion in this study is that it should be more effective to utilize the existing situation such as at the time of event coverage there must be protocol or staff from other parts present, better cooperate with other staff to process the coverage so that the news can be obtained even if the reporting team is not available at the location the same Need to make sure the rubrikasi good and so that the information presented can be separated and the reader can digest and seek information better.
\end{abstract}

Keywords:Public relations; tabloid; information; management;communication

Korespondensi: Deni Herdiansah, Universitas Padjadjaran, Jl. Raya Bandung-Sumedang Km 21, Jatinangor 45363.Email: deni.herdiansah79@gmail.com 


\section{PENDAHULUAN}

Beberapa tahun sebelumnya profesi Hubungan Masyarakat (Humas) di Indonesia adalah sebuah profesi yang jarang dibutuhkan oleh perusahaan maupun instansi pemerintah. Banyak yang mempertanyakan fungsi dari Humas itu sendiri secara kelembagaan. Namun, sekarang profesi Humas mulai dilirik sebagai bagian penting dari suatu organisasi, lembaga, perusahaan maupun instansi pemerintahan yang terbukti dengan adanya divisi Humas yang berdiri sendiri yang bukan merupakan bagian atau sub bagian dari divisi lain. Walaupun secara fungsi dan peran dari bagian Humas belum ada di taraf yang memuaskan bagi pimpinan manajemen secara kualitatif maupun kuantitatif. Hal ini dikarenakan peran kedudukan Humas belum diterapkan sebagaimana mestinya sebagai bagian yang memiliki nilai strategis bagi organisasi dan bahkan masih dianggap sebagai pemborosan.

Fungsi dari Humas sendiri adalah untuk membangun hubungan harmonis antara organisasi dengan publiknya baik itu internal maupun eksternal. Sejalan dengan apa yang disampaikan oleh Damayanti (2013) yang menyatakan bahwa selain sebagai sebuah kajian keilmuan, profesi public relations dikerjakan dengan penuh perasaan dengan menggabungkan ilmu manajemen. Dalam proses membangun hubungan yang harmonis ini tentunya memerlukan berbagai cara agar hubungan yang harmonis bisa terbangun. Salah satu caranya adalah dengan menerbitkan majalah internal, yang merupakan media komunikasi hubungan masyarakat efektif.

Majalah internal ini merupakan private publication (penerbitan bagi kalangan sendiri/ tertentu) yang dibedakan dari penerbitan commercial press (penerbitan media massa yang dijual untuk umum). Majalah internal merubah kecenderungan komunikasi yang bersifat instruktif dari pihak manajemen ke karyawan, dan majalah internal ini juga menjadikan manajemen lebih terbuka dalam membina hubungan dengan karyawan. Frank Jefkins (2004: 10) memberikan batasan bahwa definisi Humas meliputi:

"Suatu yang merangkum keseluruhan kegiatan komunikasi suatu organisasi secara terencana, baik secara internal maupun eksternal dengan publik sasarannya dalam rangka mendapatkan saling pengertian sebagai tujuan utama organisasi”.

Humas pada intinya senantiasa berkenaan dengan kegiatan-kegiatan tersebut diharapkan akan muncul suatu dampak yakni perubahan positif. Sedangkan menurut The International Public Relations Association

(IPRA) memberikan definisi terhadap Humas sebagai berikut:

"Hubungan masyarakat adalah fungsi manajemen dari perilaku yang terencana dan berkelanjutan diantara organisasi dan 
Lembaga yang bersifat umum maupun pribadi dengan tujuan untuk berupaya membina pemahaman, rasa simpati, dan dukungan dari publik sasaran melalui teknik pengumpulan pendapat umum di antara publik yang dihubungkan yang sedapat mungkin diimplementasikan berdasarkan kebijaksanaan dan tata cara pengemasan informasi yang dibuat secara terencana dan disebarkan luas, guna mencapai kerjasama yang lebih produktif dan pemenuhan kepentingan antara manajemen dengan publik sasaran yang lebih efisien" (Effendy, $2006: 21$ )

Berdasarkan apa yang disampaikan oleh IPRA tersebut, maka dapat dirumuskan bahwa definisi humas apabila dititikberatkan pada kegiatannya adalah memiliki pola komunikasi yang bersifat timbal balik diantara pimpinan manajemen dalam suatu organisasi dengan publik secara dua arah dalam rangka mendukung fungsi dan tujuan organisasi dengan cara meningkatkan proses pembinaan kerjasama dan pemenuhan kepentingan bersama (Effendy, 2006: 23).

Rosady Ruslan mengemukakan definisi humas atau public relations sebagai berikut:

"Public relations adalah bagian dari sistem manajemen dalam suatu organisasi yang memiliki fungsi untuk menilai sikap publik, mengidentifikasikan kebijaksanaan organisasi, dan tata cara seseorang atau organisasi yang dilakukan terhadap publiknya dengan berbagai program kegiatan untuk mendapatkan saling pegertian, pemahaman, dan dukungan yang berdasarkan perencanaan kepentingan umum"(Ruslan, 2013: 6-7).

Menurut The British Institute of Public relations (IPR). Public relations adalah keseluruhan upaya yang terencana dan berkesinambungan untuk menciptakan dan memelihara saling pengertian antara satu organisasi dengan segenap khalayaknya (Yulianita, 2012: 32).

Berbagai definisi mengenai humas tersebut menunjukkan bahwa fokus dari konsep humas adalah berbicara mengenai upaya yang dilakukan untuk menjalin hubungan antara organisasi dan publiknya untuk mampu saling berkomunikasi dan berhubungan dengan baik demi tercapainya tujuan organisasi. Praktisi humas dianggap berfungsi dengan baik apabila dia mampu melakukan tugas dan kewajiban sesuai dengan harapan publik (Canfield dalam Effendy, 2006: 35).

Secara umum fungsi humas adalah sebagai berikut: (1) memelihara komunikasi yang baik antara perusahaan dan publiknya. Meskipun merupakan bagian dari perusahaan, humas berada pada bagian terluar sebuah perusahaan. Seluruh informasi dari dalam menuju luar perusahaan maupun sebaliknya, harus disaring dengan baik. (2) mengabdi pada kepentingan publik dengan baik. Hubungan masyarakat harus mengetahui kebutuhan dan keinginan publik, sehingga seluruh keputusan pimpinan organisasi akan dapat diterima dengan baik oleh berbagai khalayak sasaran. Salah satu penilaian keberhasilan organisasi adalah tercermin dari 
kapabilitas dan kualitas fungsi humas dalam upaya menjalin komunikasi yang harmonis dengan publik. (3) memelihara kebiasaan tingkah laku dan moralitas manajemen suatu organisasi dengan baik melalui pemberdayaan public relations yang kredibel yang dapat mencitrakan organisasinya. Hal ini merupakan bagian tak terpisahkan dari sebuah citra korporasi (corporate Image). Praktisi public relations dianggap kredibel apabila memiliki pengetahuan dan wawasan (knowledge), kemampuan secara teknis (skillfull), kebiasaan baik(manner) dan dapat dipercaya (trustworthy).

Ruang lingkup humas berdasarkan ciri dan fungsinya diklarifikasikan menurut jenis organisasi yang terdiri dari Humas Pemerintahan dan Humas Perusahaan. (1) humas pemerintahan memiliki dua tugas utama yaitu pertama, menyebarkan informasi secara teratur mengenai kebijakan, kegiatan pemerintah, perencanaan, dan hasil yang telah dicapai oleh pemerintah selama ini; kedua, memberikan pengetahuan kepada masyarakat mengenai peraturan perundang-undangan, kebijakan pemerintah dan keputusan pemerintah lainnya yang bersangkutan dengan kehidupan rakyat, serta memberikan saran dan nasihat pada pemerintah terkait tanggapan publik terhadap kebijaksanaan yang dijalankan (Efendy, 2006: 37). Humas pemerintahan dalam menjalankan fungsinya dibedakan menjadi humas pemerintahan pusat dan humas pemerintahan daerah. Aktivitas yang dilakukan oleh kedua Humas pemerintahan tersebut tidak jauh berbeda yaitu sama dalam hal pengorganisasian dan mekanisme kerja yang bertugas untuk memberikan informasi kepada masyarakat luas (Effendy, 2006: 39).

Beberapa hal yang membedakan hanyalah ruang lingkup dan cakupan wilayah kerja, serta saat ini pemerintah daerah telah memiliki otoritas dan wewenang dalam pengelolaan daerahnya berdasarkan Undang-Undang Nomor 32 Tahun 2004 tentang Pelaksanaan Otonomi Daerah oleh Pemerintah Daerah. Sedangkan berdasarkan ruang lingkup aktivitas kehumasan pemerintah adalah sebagai berikut: (a) biro pers. Merupakan biro yang bertugas membina hubungan baik dengan media. Humas membutuhkan media sebagai sarana menyebarkan informasi dan pembentukan opini publik, begitupun sebaliknya media membutuhkan humas sebagai sumber berita, sehingga hubungan keduanya merupakan simbiosis mutualisme. (b) biro publisitas merupakan upaya pengenalan organisasi pada publik, dimana praktisi Humas di biro ini harus dapat berperan aktif seperti insan-insan pers. Praktisi humas dituntut menguasai teknik menulis agar dapat menghasilkan produk tulisan menarik yang berfungsi untuk menyebarkan informasi kepada publik. Kemampuan ini merupakan modal utama yang harus dimiliki oleh praktisi Humas, 
sebab sebagian besar tugasnya berhubungan erat dengan wartawan dan pemberitaan. (c) biro Perencanaan merupakan aktivitas humas untuk mengorganisir sebuah kegiatan dengan tujuan membentuk citra positif bagi pemerintah. Praktisi Humas diharapkan bisa melakukan perencanaan dan melaksanakan program atau kegiatan unik sehingga dapat memberikan perhatian bagi publik dan media. Selain itu, pemerintah dituntut untuk dapat mensinergikan antara komunitas dan masyarakat sekitarnya. Hal ini bisa dilakukan melalui kegiatankegiatan yang melibatkan mereka sehingga timbul rasa memiliki (sense of belonging) dalam diri komunitas tersebut. Pemerintah tidak dapat berkembang dengan baik apabila tidak mendapat dukungan dari masyarakat sekitar. (2) humas Perusahaan pada umumnya sering diidentikan dengan penyebutan public relations. Unsur manajemen dan bisnis nampak pada kegiatan yang dilakukan oleh praktisinya yang bertujuan untuk membangun citra korporat promosi (Efendy, 2006: 42). Kekhususan humas perusahaan dititikberatkan pada pelayanan publik, penyebaran informasi, dan penanggulangan krisis perusahaan. Hal ini tentunya senada dengan tujuan utama perusahaan untuk membangun citra korporat yang baik secara keseluruhan. Ruang lingkup kegiatannya hampir sama dengan humas pemerintahan, namun ada beberapa hal yang lebih ditonjolkan yang membedakan ruang lingkup kegiatan humas pemerintah dengan perusahaan adalah sebagai berikut: (1) lobbying, kegiatan lobbying dilakukan dengan melakukan persuasi dan negosiasi dengan berbagai pihak. Secara sederhana, istilah lobbying dapat didefinisikan sebagai fungsi dan peran Humas dalam menjalin dan memelihara hubungan, terutama dengan tujuan memengaruhi penyusunan regulasi. (2) social investment. corporate social responsibility (CSR) merupakan sepenggal contoh yang dapat dilakukan oleh Humas yang memberikan manfaat dan kepentingan sosial. Melalui program CSR, publik akan mempersepsikan bahwa suatu perusahaan memang peduli kepada masyarakat sehingga diharapkan menghasilkan citra yang positif.

Peran humas sangat dibutuhkan dan dianggap penting di instansi pemerintah, hal ini karena bagian humas memiliki tugas untuk dapat menyediakan berbagai macam informasi yang dibutuhkan oleh publik sehingga dengan mudah publik dapat mengetahui kegiatan dan kinerja dari lembaga pemerintahan yang menaunginya. Namun, instansi pemerintah memiliki orientasi yang berbeda dengan instansi swasta. Oleh karena itu, hubungan masyarakat pemerintah memiliki karakteristik yang berbeda dengan hubungan masyarakat di instansi swasta (non pemerintahan). Fungsi pokok humas 
pemerintahan Indonesia berdasarkan keputusan Badan Koordinasi Kehumasan (Ruslan, 2012: 343) pada dasarnya antara lain sebagai berikut: (1) mengamankan kebijakan politik pemerintahan, (2) memberikan pelayanan dan menyampaikan informasi kepada publik, (3) menjadi komunikator sekaligus sebagai mediator yang proaktif dalam rangka menjaga kepentingan dan komunikasi dua arah antara instansi dengan publik, (4) berperan serta menciptakan iklim kondusif dan menjaga stabilitas dan keamanan politik pembangunan nasional, dan (5) membuat laporan berkala terkait penyelenggaraan aktivitas dan program kehumasan.

Humas pemerintahan setidaknya memiliki dua tugas utama, yaitu: (I) menyebarkan informasisecarateraturmengenaikebijaksanaan, perencanaan dan hasil yang telah dicapai; (2) menerangkan dan mendidik publik mengenai berbagai macam regulasi peraturan perundangundangan dan hal-hal yang menyangkut dengan kehidupan masyarakat secara umum. Selain itu, humas pemerintahan memiliki tugas untuk dapat berperan menasehati pimpinan departemen dalam hubungannya menanggapi reaksi dari publik terhadap kebijaksanaan yang sedang dijalankan (Effendy, 2006: 37).

House journal adalah salah satu bentuk saluran komunikasi seorang praktisi humas yang masih tetap digunakan sampai sekarang.
Orang-orang Amerika lah yang menjadi pionir dalam pembuatan house journal sebagai media suatu perusahaan dengan munculnya berbagai house journal diantaranya The Lowell Offering (1842), The I. M. Singer \& Co's Gazette (1855) dan The Travelers Insurance Companies (perusahaan Asuransi Perjalanan) dengan Protector (1865). Kehadiran house journal membuktikan bahwa penerbitan media ini bukan kegiatan baru bagi public relations atau hanya kegiatan penunjang saja, Karena adakalanya penggunaan media seperti pers, radio, atau televisi tak lagi sesuai, apalagi jika khalayak terdiri dari kelompok kecil contohnya seperti para staf atau anggota organisasi sendiri yang mungkin hanya dapat dijangkau melalui house journal /jurnal internal. Dalam kaitannya dengan organisasi dan komunikasi internal biasanya dalam komunikasi internal organisasi sendiri house journal terdiri dari beberapa macam bentuk diantaranya: (1) house journal (jurnal internal), (2) video, (3) slide, (4) kaset rekaman audio, (5) kursus pendidikan dan pelatihan tambahan, (6) ucapan-ucapan lisan, (7) seminar konferensi, dan (8) eksibisi khusus (Jefkins, 2004: 145).

Istilah jurnal diartikan secara luas yakni sebagai tulisan yang diterbitkan secara berkala atau suatu hasil kumpulan informasi publik internal yang berupa bahan cetakan yang diterbitkan secara teratur (Jefkins, 2004: 147). 
Adapun bentuk dari house journal /jurnal internal cukup bervariasi antara lain sebagai berikut: (1) magazine. house journal dengan format majalah berukuran A4 (297 x 110 $\mathrm{mm}$ ), dengan isi kebanyakan adalah tulisan fitur dan ilustrasi. Jurnal ini bisa dicetak dengan menggunakan teknik lithografi dan photogravure, dan biasanya diterbitkan setiap bulan atau triwulan, (2) newsletter berisi pokok berita yang diperuntukkan untuk pembaca sibuk. Biasanya memiliki jumlah halaman 2 hingga 8 halaman berukuran A4, percetakan menggunakan teknik lithografi atau dapat diproduksi pada mesin fotocopy kantor, (3) tabloid newspaper, mirip dengan surat kabar populer (umum) dan berisikan artikel pendek, dan ilustrasi. Diterbitkan mingguan, dwiminggu, bulanan, atau setiap dua bulan sekali, (4) wall newspaper, bentuk media komunikasi staf/ karyawan di perusahaan, pabrik, atau pasar swalayan, atau lebih dikenal dengan nama mading (majalah dinding). Bentuknya seperti poster kecil yang ditempelkan pada dinding, yang juga tak terbatas pada publik internal saja namun publik eksternal juga bisa melihat dan membaca informasi yang ada, dan (5) sales buletin, adalah buletin yang digunakan sebagai media informasi dan komunikasi yang bersifat teratur antara sales manajer dengan bawahannya (salesman) yang terbit secara akhir pekan. Contohnya adalah PT. Caltex Pasific yang telah menerbitkan buletin perusahaan selama kurang lebih sudah 43 tahun yang berisi berita perusahaan dan pokok-pokok berita umum (Soemirat, 2012: 23).

Majalah internal merupakan sebuah media yang harus dibuat dan dikelola oleh seorang humas karena ini merupakan bagian penting dari pembinaan hubungan dengan karyawan dan juga sebagai sarana komunikasi manajemen dengan bawahannya dengan tujuan untuk menciptakan citra baik dan mencegah timbulnya citra kurang baik dan mengurangi isu negatif yang timbul dan membuat opini publik, karena itulah majalah internal dibuat dengan tujuan untuk membina hubungan baik dengan publik agar timbulnya citra yang baik dan terbentuknya opini publik.

Instansi pemerintahan tentunya pasti memiliki humas, di dalam instansi Pemerintah Sekretaris Daerah Ciamis sendiri humas lebih dikenal dengan nama bagian humas (Bagian Hubungan Masyarakat), seperti yang kita ketahui bahwa humas memiliki banyak tugas seperti mengurus kegiatan dari segi protokoler, media monitoring, publikasi dan dokumentasi, dan juga pembuatan majalah internal yang lebih dikenal dengan nama "Tabloid Dinamis" (Dinamika Pembangunan Ciamis). Tabloid Dinamis ini memiliki konten utama tentang pembangunan wilayah Ciamis dan programprogram yang dilaksanakan oleh kepala daerah 
beserta dinas-dinas yang terkait di pemerintahan kabupaten Ciamis yaitu bupati, wakil bupati, dan sekretaris daerah (Sekda). Pengumpulan bahan-bahan informasi berita Tabloid Dinamis didapat dari hasil liputan tim publikasi dan dokumentasi Sekda Kabupaten Ciamis dengan periode penerbitan majalah ini adalah setiap dua bulan sekali.

Selain untuk membangun hubungan dengan publiknya Tabloid Dinamis juga merupakan bukti nyata hasil kerja keras para pegawai Sekda dan instansi pemerintahan di Kabupaten Ciamis yang mana Tabloid Dinamis ini menjadi penghargaan tersendiri dan bukti bahwa kerja keras mereka tidak sia-sia. Majalah internal seperti Tabloid Dinamis hanya diterbitkan oleh kantor Sekda (Sekretariat Daerah) Kabupaten Ciamis dan tidak ada intansi pemerintahan lain di lingkungan Pemerintahan Kabupaten Ciamis yang mengeluarkan majalah internal seperti Tabloid Dinamis. Hal inilah yang melatar belakangi penulis untuk menggali lebih dalam mengenai pengelolaan Tabloid Dinamis.

Berdasarkan latar belakang yang sudah dipaparkan, peneliti ingin dapat mengkaji dan mengungkapkan fenomena peranan humas pemerintahan dalam pembuatan dan pendistribusian media internal dalam sebuah tulisan tentang: "bagaimana pembuatan Tabloid Dinamis oleh Bagian Humas Setda (Sekretariat Daerah) Pemerintah Kabupaten Ciamis".

\section{METODE PENELITIAN}

Metode yang digunakan oleh penulis dalam penelitian ini berjeniskan metode deskriptif. Dalam metode deskriptif ini tidak dimaksudkan untuk mengadakan pengujian dan menjelaskan hubungan, tetapi lebih memfokuskan untuk mencari dan menemukan fenomena tertentu dari suatu kasus atau peristiwa yang terjadi di tempat penelitian. Adapun pengertian metode penelitian deskriptif menurut Jalaluddin dalam bukunya Metode Penelitian Komunikasi yang mengutip pendapat Isaac dan Michael, metode deskriptif bertujuan untuk melukiskan secara terstruktur mengenai fakta atau ciri populasi tertentu atau bidang yang dilakukan berdasarkan nilai faktual dan cermat (Isaac dan Michael dalam Rakhmat, 2007: 22). Sedangkan paradigma yang digunakan adalah paradigma postpositivistik, yaitu melihat realitas sebagai hal yang memang ada dalam kenyataan sesuai dengan hukum alam, namun manusia belum tentu bisa melihatnya secara benar (Rizkahaj dan Wahyuni, 2017: 51)

Penulis memaparkan situasi atau peristiwa yang berkaitan dengan kegiatan Pembuatan Tabloid Dinamis oleh Bagian Humas Setda (Sekretariat Daerah) Kabupaten Ciamis.

\section{HASIL DAN PEMBAHASAN}

House journal adalah sebuah media 
komunikasi internal yang dapat kita temukan di instansi manapun terutama instansi yang memiliki cakupan publik yang luas. Media komunikasi house journal diperlukan untuk mencapai citra positif dan dukungan opini publik, selain penggunaan media yang tak bisa dikendalikan oleh seorang hubungan masyarakat yaitu media massa atau pers. Bentuk dan isi dari house journal ini tak jauh berbeda dengan pers komersial, hanya saja berbeda menyangkut pembaca yang terbatas tidak berbentuk massa (umum), segmentasi publik pembacanya lebih khusus sesuai target perusahaan/instansi tersebut. Tabloid internal Dinamis sudah diterbitkan sejak tahun 2009. Seiring dengan bergulirnya masa jabatan dan bergantinya pejabat yang mengurus Tabloid Dinamis, banyak terjadi perubahan baik dari format, desain, rubrikasi hingga frekuensi terbit. Tabloid Dinamis terbit satu kali dalam dua bulan yang didistribusikan ke seluruh instansi yang dinaungi dan berhubungan dengan kantor Setda (Sekretariat Daerah) Kabupaten Ciamis.

Tabloid Dinamis adalah media internal dari kantor Setda (Sekretariat Daerah) Kabupaten Ciamis yang berfungsi sebagai pelaksanaan dari tugas pokok fungsi Sekda yang diturunkan menjadi tugas pokok fungsi bagian yang kemudian diturunkan ke bagian humas yang kemudian diturunkan lagi ke sub bagian informasi dan publikasi yang sekarang diubah menjadi sub bagian dokumentasi dan publikasi yang salah satu tugas pokoknya adalah penyebarluasan informasi pembangunan daerah Kabupaten Ciamis dan Tabloid Dinamis merupakan/sebagai media dalam menyebarluaskan informasi pembangunan daerah Kabupaten Ciamis yang khususnya dilaksanakan oleh pemerintahan Kabupaten Ciamis, Pemerintah Pusat, atau dari pemerintah Provinsi Jawa Barat yang dilaksanakan di daerah Kabupaten Ciamis. Penyebaran informasi ini merupakan bagian dari amanat UU Keterbukaan Informasi Publik yang harus dilakukan oleh instansi pemerintahan. Di mana menurut Susanto (2013) informasi merupakan salah satu faktor yang mampu menjaga konsistensi pelayanan publik yang dilakukan oleh instnasi pemerintahan.

Seiring dengan perkembangannya, pembaca Tabloid Dinamis tak hanya disebarkan kepada publik bersangkutan, yaitu Kantor Setda (Sekretariat Daerah) Kabupaten Ciamis saja, namunsetiapinstansipemerintahandan beberapa perusahaan yang ada di Kabupaten Ciamis menjadi pembaca sekaligus jalur distribusi dari Tabloid Dinamis, hal ini bertujuan agar setiap pihak instansi pemerintahan dan perusahaan dapat mengetahui alur dari pembangunan Daerah Kabupaten Ciamis. Sebuah penerbitan sangatlah penting untuk merumuskan terlebih dahulu siapa readers/pembacanya. Oleh karena 
itu pembaca merupakan faktor utama serta objek penting yang harus diperhatikan dalam menentukan sebuah isi atau konten dari tabloid tersebut. Menurut keterangan dari narasumber yaitu bapak Memet Hikmat:

"Sasaran dari Tabloid Dinamis adalah Aparatur pemerintahan, Mitra Pemerintah seperti PDAM, BUMD, BUMN, Bank, termasuk instansi-instansi vertikal seperti Pengadilan, Kejaksaan, TNI, Kodim dan Polisi.”

Hal ini sejalan dengan yang dikemukakan

Soemirat yaitu:

"Sebuah penerbitan perlu memperjelas siapa target pembacanya, kejelasan atas sasaran pembaca akan membuat para pekerja redaksi selalu bekerja dengan bayangan pembaca dalam pikirannya, serta memudahkan pengelolaan penerbitan dalam berkomunikasi dengan pembaca mereka" (Soemirat, 2012: 34).

Dengan jelasnya target dan sasaran dari pembaca tentunya kita dapat merumuskan: (1) apa harus disajikan kepada pembaca? Dengan target/sasaran yang diperuntukkan dengan lembaga ke pemerintahan dan perusahaan yang berada di Kabupaten Ciamis maka dapat disimpulkan informasi yang akan disajikan kepada pembaca adalah informasi tentang pembangunan daerah Kabupaten Ciamis yang bertujuan untuk penerangan dan membina hubungan baik dengan internal dari Setda Kabupaten Ciamis dan publik bersangkutan, (2) jenis informasi apa yang harus diberikan? Pembaca Tabloid Dinamis adalah instansi- instansi pemerintahan/aparatur pemerintahan dengan melihat kepadatan aktivitas yang berbeda-beda tiap instansi maka informasi yang disajikan berupa informasi yang tetap mengacu pada pembangunan daerah Kabupaten Ciamis, dan (3) apakah informasinya bersifat umum atau khusus? Informasi dalam Tabloid Dinamis pada khususnya berisi penerangan tentang pembangunan Kabupaten Ciamis. Dan pada umumnya Tabloid Dinamis berisi tentang perkembangan budaya dan prestasi Kabupaten Ciamis.

Proses perencanaan program kerja melalui beberapa proses atau langkah-langkah pokok yang menjadi landasan acuan untuk pelaksanaan program kerja kehumasan (Ruslan, 2012: 148150) adalah sebagai berikut: (1) penelitian dan mendengarkan (Research-Listening). Dalam tahap ini, penelitian yang dilakukan berkaitan dengan opini, sikap dan reaksi dari mereka yang berkepentingan dengan aksi dan kebijaksanaankebijaksanaan suatu organisasi. Setelah itu baru dilakukan evaluasi fakta-fakta, dan informasi yang masuk untuk menentukan keputusan berikutnya. Pada tahap ini akan ditetapkan suatu fakta dan informasi yang berkaitan langsung dengan kepentingan organisasi, yaitu What's our Problem? (Apa yang menjadi problem kita?), (2) perencanaan dan mengambil keputusan (Planning-Decision). Dalam tahap ini, sikap, opini, ide-ide, dan reaksi yang berkaitan dengan 
kebijaksanaan serta penetapan program kerja organisasi yang sejalan dengan kepentingan atau keinginan-keinginan pihak yang berkepentingan mulai diberikan: Apa yang kita Kerjakan, (3) mengkomunikasikan dan melaksanakan (Communication and Action). Dalam tahap ini Informasi yang berkenaan dengan langkahlangkah yang akan dilakukan dijelaskan sehingga mampu menimbulkan kesan-kesan yang secara efektif dapat memengaruhi pihakpihak yang dianggap penting dan berpotensi memberikan dukungan sepenuhnya: Here's what we did and why? (Apa yang telah kita lakukan dan mengapa begitu?), dan (4) mengevaluasi. Pada tahap ini public relations atau hubungan masyarakat mengadakan penilaian terhadap hasil-hasil dari program-program kerja atau aktivitas humas yang telah dilaksanakan. Termasuk mengevaluasi efektivitas dari teknikteknik manajemen dan komunikasi yang telah dipergunakan: How did we do? (Bagaimana yang telah kita lakukan?).

Perencanaan isi dan rubrikasi dari Tabloid Dinamis selalu dilakukan dengan mengadakan rapat penerbitan sebelumnya rapat penerbitan dilakukan pada awal tahun yang membahas apa input dan output dan apa outcome yang dihasilkan. Setelah dilakukan rapat dan semua disetujui lalu setiap dilakukan pengagendaan kegiatan yang akan dilakukan dalam satu tahun yang kemudian dirinci menjadi per-bulan dan kemudian diperinci kembali menjadi per-hari, dan hasil pengagendaan ini akan dimasukan ke agenda peliputan untuk mengumpulkan informasi.

Awalnya rubrikasi Tabloid Dinamis terdiri dari beberapa rubrik yaitu ideologi, politik, sosial, budaya, ketahanan dan keamanan, kesehatan dan pendidikan. Tak dijelaskan isi rinci dari tiap rubrik tersebut dikarenakan pergantian pejabat dan pengurus humas yang menangani Tabloid Dinamis.

"Sekarang tak ada rubrikasi yang pasti bahkan bisa dibilang tidak ada rubrikasi dalam Tabloid Dinamis, dikarenakan kurangnya sumber daya manusia yang tidak memungkinkan untuk mengurus rubrikasi yang mana pada saat ini setiap staf yang mengurus Tabloid Dinamis memiliki tugas lebih dari satu dari mulai meliput, membuat berita sampai harus membuat tabloid sampai menjadi siap edar. Hal ini sangatlah tidak memungkinkan dilakukan oleh staf terbatas seperti sekarang" (Memet Hikmat, 2017).

Tabloid Dinamis sekarang berisi tentang pembangunan Kabupaten Ciamis, kegiatan bupati dan wakil bupati, dan sekda Kabupaten Ciamis. Yang mana berita ini didapat dari hasil kegiatan peliputan kegiatan dari para pemimpin daerah. Dalam Tabloid Dinamis lebih dominan berita dengan bentuk straight news yang diselingi satu dua feature yang mana itu pun tergantung dari ketersediaan berita yang dapat dibuat menjadi feature. Pada dasarnya perubrikasian Tabloid Dinamis sangat buruk karena tidak ada perubahan dalam rubrikasi 
yang dapat menyebabkan kebosanan pembaca selain itu tak ada upaya untuk merubahnya. Menurut Hardiman Untuk menghindari kebosanan pembaca ada baiknya setiap dua tahun sekali isi redaksional dan perwajahan diperbaharui (Hardiman, 2008: 98).

Penulisan berita yang disiapkan untuk isi dan rubrikasi Tabloid Dinamis dikelola secara inhouse, artinya semua proses penulisan dilakukan oleh karyawan dari divisi humas Setda Kabupaten Ciamis, hal ini juga berdasarkan SK bupati tiap tahunnya ada yang mengatur pembuatan dari Tabloid Dinamis adalah dari bagian humas Setda Kabupaten Ciamis hal ini dikarenakan adanya pengurangan anggaran untuk produksi Tabloid Dinamis sehingga sangat tak memungkinkan menyewa tenaga dari luar bagian humas Setda Kabupaten Ciamis.

Persentase isi Tabloid Dinamis tidak bisa dijelaskan secara detail namun penyajian informasi tentang pembangunan Kabupaten Ciamis lebih ditekankan, setelah itu kegiatan bupati, wakil bupati dan sekda Kabupaten Ciamis dalam menjalankan tugasnya sebagai laporan pada tiap instansi yang masuk ke dalam sirkulasi dari Tabloid Dinamis. Lalu terakhir adalah informasi tentang prestasi dan budaya khas Kabupaten Ciamis yang biasa hanya dipasang di halaman tengah.

Perencanaan isi dan rubrikasi seperti ini tentunya kurang baik karena akan memengaruhi dalam pemilihan konten selain itu juga akan berpengaruh pada pembaca yang akan bosan dengan isi yang bersifat formal saja sehingga akan mengurangi keefektifan dari Tabloid Dinamis, hal ini dikarenakan tidak idealnya komposisi isi dari Tabloid Dinamis itu sendiri. hal ini berbeda dengan yang dikemukakan oleh Thomas H. Bivins dalam buku Inhouse Magazine yaitu: komposisi isi redaksional yang ideal untuk media internal cetak baik berbentuk Newsletter maupun majalah adalah sebagai berikut:

"50 persen informasi tentang organisasi 20 persen informasi karyawan: kondisi lingkungan kerja, peraturan perusahaan, kenaikan gaji dan promosi, 20 persen Informasi non organisasi: pesaing, konsumen, masyarakat luas 10 persen hiburan, opini, dan hobi" (Hardiman, 2008: 96).

Berdasarkan pernyataan tersebut dapat disimpulkan bahwa Tabloid Dinamis masih belum ideal karena informasi yang disajikan lebih dominan informasi internal.

Tim produksi Tabloid Dinamis selalu membiasakan menggunakan penulisan $5 \mathrm{~W}+$ 1H. humas Setda Kabupaten Ciamis menyadari bahwa Tabloid Dinamis dibaca oleh orang yang memiliki mobilitas tinggi sehingga penulisan $5 \mathrm{~W}+1 \mathrm{H}$ selalu digunakan agar para pembaca dapat mengerti dan memahami berita dengan waktu yang singkat. Hal ini sejalan dengan yang dikatakan oleh Patmono dalam Soemirat dan Ardianto yaitu: 
"Berita (stright news) merupakan salah satu bentuk tulisan jurnalistik yaitu tulisan yang berisi laporan langsung yang hanya memuat fakta kejadian dan sarat dengan informasi. Sifat tulisan ini padat, lugas, singkat dan jelas memenuhi unsur-unsur $5 \mathrm{~W}+1 \mathrm{H}$. Berbeda dengan kaidah tulisan lain yang mulai dari yang tidak penting menuju klimaks. Berita dimulai dengan fakta yang paling penting. Struktur berita dikenal dengan piramida terbalik. Semakin ke bawah tulisan itu, isi atau informasi yang disajikan semakin tidak penting" (Soemirat dan Ardianto, 2012: 38).

Selain itu dalam pemilihan berita news value sangat diperhatikan. Berita yang memiliki news value lebih juga diutamakan selain lebih penting juga karena terbatasnya halaman dari Tabloid Dinamis yang hanya memiliki dua belas halaman di setiap edisinya. Hal ini sesuai dengan yang dikemukakan oleh Soemirat yaitu: "Pendekatan kualitatif adalah pemilihan informasi berdasarkan kualitas informasi yang mengacu pada tinggi rendahnya nilai berita dan berharga tidaknya berita. Pendekatan kuantitatifadalah usahamemuat informasi dalam rubrik berdasarkan jumlah halaman yang telah ditentukan" (Soemirat dan Ardianto, 2012: 34-35).

Narasumber mengungkapkan bahwa dalam mencari informasi sebagai isi dari Tabloid Dinamis hanya dilakukan dengan satu cara yaitu dengan meliput acara. Tim peliput dari humas Setda Kabupaten Ciamis meliput setiap kegiatan yang dilaksanakan dan sudah diagendakan.

Peliputan atau pengumpulan informasi untuk Tabloid Dinamis dilakukan oleh petugas peliputan dari bagian humas Setda
Kabupaten Ciamis pengumpulan informasi dan dokumentasi terbatas pada hasil fotografi saja sedangkan rincian kegiatan bisa diminta ke sub bagian protokoler yang mengelola acara dan wawancara terbatas pada beberapa orang yang dapat meningkatkan nilai dari berita. Informasi yang didapat dari hasil peliputan kemudian diolah menjadi tulisan berita dan dilampirkan gambar kegiatan hasil dari peliputan. Tak semua hasil peliputan diolah langsung menjadi berita. Kegiatan penulisan biasanya dilakukan di waktu saat jadwal acara peliputan sedang kosong dan hanya beberapa berita yang dianggap penting saja yang langsung dibuat berita. Pengumpulan bahan penulisan berita dilakukan dengan mengumpulkan bahan siap olah yaitu seperti yang dikemukakan Siregar pengumpulan bahan siap olah mempunyai arti bahwa bahan harus dihimpun dulu sebelum diolah menjadi tulisan atau foto. Kegiatan ini lazim disebut peliputan (Siregar, 2004: 163).

Hasil tulisan kemudian dikirim ke Diskominfo Ciamis untuk penerbitan web dan disebarkan ke wartawan. Berita yang diberikan pada wartawan biasanya berupa gambar yang berisi tulisan dan photo release yang dimuat dalam satu gambar. Namun meskipun selalu dirilis pada wartawan biasanya wartawan langsung datang ke bagian humas Setda Kabupaten Ciamis untuk mendapatkan berita. Desain adalah seni artistik mengenai keindahan. 
Jika kita kaitkan dengan sebuah media internal yang berbentuk tabloid, desain mencakup tata letak, gaya huruf dan layout. Saat ini bidang desain adalah bidang yang digunakan dalam bidang apapun bukan hanya sebagai fungsi keindahan namun juga sebagai nilai tambah komunikatif bagi sebuah tabloid. Sselain itu desain membuat sebuah tabloid memiliki karakteristik dan ciri khas tersendiri yang tentunya sesuai dengan visi, misi dan budaya perusahaan. Salah satu tujuan diterbitkannya Tabloid Dinamis adalah untuk menambah rasa cinta dan bangga masyarakat Ciamis terhadap Kabupaten Ciamis. Karenanya Tabloid Dinamis juga dapat dijadikan sebagai indikator penyebab rasa bangga masyarakat terhadap Kabupaten Ciamis. Tim redaksi Tabloid Dinamis mengemukakan bahwa Tabloid Dinamis memiliki ciri khas karakter yang tak berubah dan tetap di pertahankan. Nama Dinamis merupakan akronim dari Dinamika Pembangunan Ciamis yang menggambarkan apa yang akan dimuat di Tabloid Dinamis dan slogan ini mengingatkan fungsi dan tujuan dari Tabloid Dinamis ini dari awal penerbitan.

Logo dan sistem tata letak (layout) Tabloid Dinamis tidak banyak berubah sejak awal penerbitan. Hal ini dikarenakan kurangnya sumber daya manusia dan padatnya jadwal yang harus dikejar tim redaksi dengan jumlah sumber daya manusia yang sangat minim. Perubahan pada Tabloid Dinamis hanya dilakukan pada bagian cover yang tadinya berbentuk kolase sesuai dengan isi dari tabloid diubah untuk memudahkan pembaca yang mayoritas berumur lebih dari 30 tahun yang penglihatannya mulai menurun karena faktor usia, bagian cover yang tadinya berbentuk kolase diubah dengan hanya menampilkan dua photo ukuran besar yang dibarengi dengan judul berita yang dimuat. Sedangkan secara keseluruhan tak banyak berubah karena faktor sumber daya manusia yang mengolah Tabloid Dinamis sangat minim.

Teks yang digunakan umumnya menggunakan font bookman old style yang mempunyai karakter standar (tidak tebal dan tidak tipis) dengan maksud agar pembaca tidak cepat lelah dan jelas saat membaca Tabloid Dinamis. Jenis font untuk judul berita dibebaskan dengan syarat mudah terbaca. Logo yang dipasang dalam Tabloid Dinamis meliputi dua logo yaitu logo dari Kabupaten Ciamis dan logo dari Tabloid Dinamis itu sendiri yang didominasi oleh warna ungu sesuai dengan logo dan warna khas kabupaten Ciamis yaitu ungu yang sudah menjadi identitas dari ciamis itu sendiri. Tidak hanya teks dalam Tabloid Dinamis juga terdapat gambar sebagai penunjang tiap berita yang disajikan, gambar yang disajikan harus memiliki resolusi yang tinggi untuk menghindari gambar pecah. Untuk backround setiap halaman menggunakan 
background alun-alun Ciamis yang menjadi pusat Kota Ciamis dengan gambar hitam putih agar tidak mendominasi apa yang disajikan.

Menurut Memet Hikmat yang bertugas mendesain Tabloid Dinamis mengungkapkan bahwa Tabloid Dinamis terdiri dari beberapa bagian yang diperhatikan dalam pembuatannya yaitu diantaranya: (1) kulit (cover). Dalam cover Tabloid Dinamis dimuat beberapa hal penting yang menjadi identitas dari tabloid yaitu logo tabloid, judul penunjuk tabloid, gambar salah satu berita yang menjadi berita paling utama dalam Tabloid Dinamis, edisi tabloid dan foto bupati dan wakil bupati yang dipasang di bagian atas cover dan di bagian cover bawah bertuliskan visi Ciamis yang mengikuti masa jabatan bupati. Memet Hikmat mengungkapkan bahwa bagian header dari Tabloid Dinamis yang terdiri dari logo tabloid, logo Kabupaten Ciamis, edisi dan foto bupati dan wakil bupati dipatenkan untuk menghindari perubahan serta agar menjadi ciri khas dari Tabloid Dinamis. Untuk Tabloid Dinamis dibuat dengan huruf yang mudah dibaca, simpel dan jelas agar memudahkan para pembaca. Edisi Tabloid Dinamis selalu dicantumkan di bagian cover atas ukuran huruf untuk penulisan edisi dibuat agak kecil agar tidak terlalu menonjol. Sedangkan bagian cover belakang diisi dengan foto-foto yang dianggap merupakan foto terbaik hasil dari peliputan selama kegiatan oleh peliput dan juga sebagai penghargaan bagi peliput atas kerja kerasnya dalam meliput.

Gambar cover Tabloid Dinamis: (1). tulisan utama. Tabloid Dinamis tidak memiliki bagian daftar isi sehingga langsung masuk ke halaman utama sehingga setelah bagian cover langsung masuk tulisan utama yang memuat berita dari kegiatan bupati, wakil bupati, dan sekda kabupaten Ciamis serta memuat pembangunan kabupaten Ciamis. Di akhir tahun tulisan utama juga diisi dengan laporan pencapaian pembangunan selama satu tahun yang didapat dari BAPPEDA yang terdiri dari foto, grafik dan tulisan rinci secara kronologis kegiatannya. (2) halaman tengah. Halaman tengah Tabloid

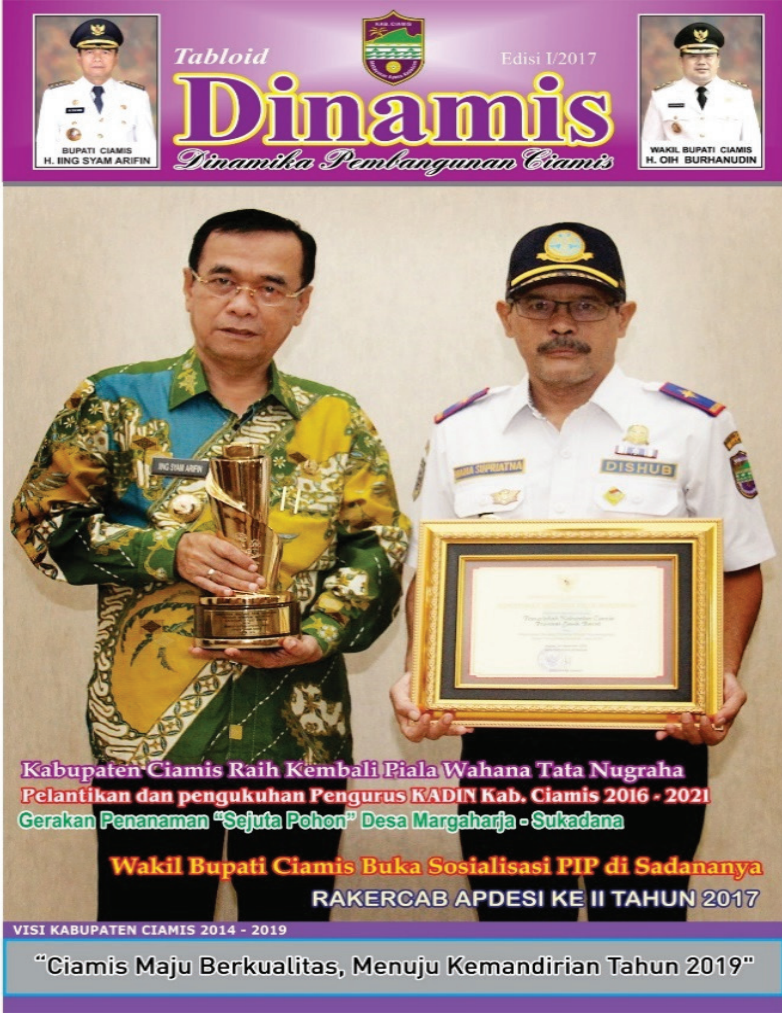

Sumber: Data Peneliti 2017

Gambar 1 Cover Tabloid Dinamis 
Dinamis diisi dengan berita budaya dan prestasi kabupaten Ciamis yang fungsinya sebagai media internal yang menginformasikan hasil kerja keras pemerintahan Kabupaten Ciamis dan juga untuk melestarikan budaya kabupaten Ciamis. Halaman tengah dipilih karena merupakan halaman berwarna selain cover depan dan belakang sehingga merupakan halaman yang strategis yang pasti dilihat dan dibaca oleh pembaca.

Menurut Hadiman, perwajahan sebuah majalah meliputi cover muka, halaman isi hingga cover belakang sebaiknya memiliki lima aspek yaitu: (1) orisinalitas dapat dicapai jika desainer menghayati benar tujuan media dan karakter pembaca, (2) mudah dibaca, pemilihan warna dan tipografi menentukan apakah sebuah desain mudah dibaca dan dipahami, (3) warna dan desain hendaknya disesuaikan dengan isi tulisan, (4) ruang kosong (white space) selain memperindah desain juga membuat halaman majalah nyaman dibaca, dan (5) konsistensi. Desain majalah yang baik adalah konsistensi dalam penggunaan dan penempatan unsurunsur desain (logo, foto, ilustrasi), pembagian kolom dan margin pemilihan font, penentuan halaman warna (Hadiman, 2008: 153).

Tabloid Dinamis bisa dikatakan memiliki lima aspek tersebut dari segi orisinalitas desain Tabloid Dinamis merupakan desain orisinal dari bagian humas Setda Kabupaten Ciamis yang sudah memiliki master desain dari awal pembuatan. Selain itu pemilihan huruf untuk tulisan Tabloid Dinamis disesuaikan dengan usia pembaca yang penglihatannya sudah mulai menurun, dari segi pemilihan warna pada desain cover dipilih warna ungu yang merupakan ciri khas Ciamis sedangkan untuk tulisan Tabloid Dinamis memilih warna hitam pekat agar memudahkan pembaca.

Meskipun dalam penyediaan ruang kosong (white space) dari Tabloid Dinamis kurang diperhatikan karena mengejar banyaknya berita yang dimuat, dan dari segi konsistensi tabloid memiliki konsistensi yang baik dimana penggunaan unsur-unsur desain selalu konsisten tiap penerbitannya. Menurut Frank Jefkins dalam buku Public relations mengungkapkan bahwa: frequency (waktu terbit atau edisi) house journal harus diterbitkan secara teratur dan memiliki tanggal publikasi yang tetap. Apakah harian, mingguan, bulanan, dua bulan sekali atau setiap triwulan, yang penting tidak ada celah yang terlalu besar karena akan menghilangkan pengertian dari keberkalaan atau kontinuitas terbit (Jefkins, 2004: 148).

Tabloid Dinamis pada tahun 2017 diterbitkan setiap 1 (satu) kali dalam dua bulan dengan format 12 halaman. Sehingga dalam 1 (satu) tahun terbit dalam 6 edisi yang setiap tahunnya penomorannya dimulai dari nomor 1 (satu). Namun meskipun demikian 
tak jarang terjadi keterlambatan dalam waktu penerbitannya sehingga mengganggu penerbitan selanjutnya. Pemilihan waktu dua bulan 1 (satu) kali ini dikarenakan kurangnya sumber daya manusia dalam proses pengelolaannya, pemilihan ini sudah tepat untuk mengurangi dampak dari kurangnya sumber daya manusia sehingga ada renggang waktu yang cukup dalam pengelolaannya. Jumlah eksemplar Tabloid Dinamis adalah 1250 eksemplar kecilnya jumlah cetak untuk Tabloid Dinamis dikarenakan terbatasnya dana percetakan dan juga kenaikan harga pencetakan yang tadinya dihargai Rp. 4.500/eksemplar sekarang menjadi Rp. 6.500/eksemplar sehingga tim penerbit tak mampu mencetak dalam jumlah yang banyak. Dengan kata lain jumlah eksemplar yang dicetak untuk Tabloid Dinamis didasarkan pada ketersediaan dana bukan pada banyaknya jumlah dari pembaca yang ditargetkan.

Hal ini tidak sesuai dengan yang dinyatakan oleh Jefkins yaitu:

"Quantity (tiras/oplah, eksemplar) jumlah dari house journal yang diterbitkan tentu harus disesuaikan dengan jumlah konsumen. Karena jumlah tiras atau eksemplar akan memengaruhi metode produksi serta kualitas materi maupun kandungan isi dari house journal" (Jefkins, 2004: 148).

Proses percetakan baru akan dimulai setelah semua data untuk percetakan Tabloid Dinamis selesai dan sudah dikirim ke pihak ketiga proses percetakan. Pihak humas Setda Kabupaten Ciamis mengirim data berupa file kepada pihak percetakan dan kemudian pihak percetakan melakukan pengecekan mengenai kelengkapan filenya, yang selanjutnya akan dibuat plate besi untuk pencetakan, model pencetakan yang digunakan adalah cetak offset yang menggunakan plat-plat besi atau biasa disebut proses cetak tidak langsung.

"Pada dasarnya cetak offset berdasarkan pada proses kimiawi seperti ritrografi (saling tolak antara lemak dan air). Cetak offset (termasuk proses cetak di atas) menggunakan plat-plat logam. Proses cetak ini disebut proses cetak tidak langsung" (Soemirat, 2012: 49-53).

Kegiatan pencetakan Tabloid Dinamis sepenuhnya diserahkan ke pihak ketiga yaitu CV. Parahiyangan-Tasikmalaya, yang mana sudah menjadi mitra dengan humas Setda Kabupaten Ciamis. Artinya dalam proses pencetakan Tabloid Dinamis humas Setda Kabupaten Ciamis tidak terjun langsung menangani melainkan hanya menjadi penerima tercetaknya Tabloid Dinamis. Dalam pencetakannya, anggaran yang diberikan untuk pencetakan Tabloid Dinamis disesuaikan dengan anggaran yang disediakan oleh pihak pimpinan sehingga pihak humas tak bisa mencetak dalam jumlah yang terlalu banyak, jadi dapat dikatakan eksemplar yang dicetak tak memiliki konsistensi melainkan berdasarkan dana yang diterima. Namun Bapak Memet Hikmat mengungkapkan bahwa secara 
umum Tabloid Dinamis dicetak dengan jumlah 1250 eksemplar.

Proses pendistribusian Tabloid Dinamis dilaksanakan pada awal bulan di bulan penerbitan baru. Tanggal tak menjadi acuan dari pendistribusian Tabloid Dinamis karena banyak faktor yang dapat membuatnya menjadi lebih cepat atau bisa juga lebih lambat yang tidak sesuai dengan perencanaannya. Pendistribusian Tabloid Dinamis sendiri cenderung mengabaikan aktualitas penerbitan. Hal ini tidak sejalan dengan yang diungkapkan Jefkins yaitu: Pendistribusian house journal harus diperhitungkan aktualitas penerbitan. Penyampaian house journal bisa dikirim melalui kurir (ditangani sendiri), via pos, atau digabung dengan sirkulasi pers komersial (Jefkins, 2004: 150).

Kegiatan Pendistribusian Tabloid Dinamis Ditangani sendiri oleh bagian humas Setda Kabupaten Ciamis yang artinya pegawai dari bagian humas Setda Kabupaten Ciamis menjadi kurir yang mengantarkan Tabloid Dinamis. Kegiatan pendistribusian Tabloid Dinamis Dibagi menjadi 2 lingkup yaitu yang pertama lingkup pemerintahan kota dan instansi kota yang terdiri dari: (1) Dewan Perwakilan Rakyat Daerah Pemerintah Kabupaten Ciamis (Jl. Insinyur H. Djuanda No.164, Ciamis, Kec. Ciamis, Kabupaten Ciamis, Jawa Barat 46211), (2) Kepolisian Resort Ciamis (Jl.
Jenderal Sudirman No.271, Sindangrasa, Kec. Ciamis, Kabupaten Ciamis, Jawa Barat 46215), (3) Kantor Samsat Kab. Ciamis (Jl. Jenderal Sudirman No.243, Sindangrasa, Kec. Ciamis, Kabupaten Ciamis, Jawa Barat 46215), (4) Cabang Pelayanan Dinas Pendapatan Daerah Provinsi Wilayah Kabupaten Ciamis (J1. Jend. Sudirman No.231, Sindangrasa, Kec. Ciamis, Kabupaten Ciamis, Jawa Barat 46215), (5) Pengadilan Negeri Ciamis (Jl. Jenderal Sudirman, Ciamis, Kec. Ciamis, Kabupaten Ciamis, Jawa Barat 46211), (6) Inspektorat Pemerintah Kabupaten Ciamis (JL. Mr. Iwa Kusumasumantri, No. 4, Ciamis, Kec. Ciamis, Kabupaten Ciamis, Jawa Barat 46211), (7) Kantor Bupati Ciamis (Jl. Jenderal Sudirman No.16, Ciamis, Kec. Ciamis, Kabupaten Ciamis, Jawa Barat 46211), (8) Setda Kab. Ciamis (J1. Jenderal Sudirman No.16, Ciamis, Kec. Ciamis, Kabupaten Ciamis, Jawa Barat 46211), (9) Badan KB dan Pemberdayaan Masyarakat Pemerintah Kabupaten Ciamis (Jl. Jenderal Ahmad Yani No.38, Kertasari, Kec. Ciamis, Kabupaten Ciamis, Jawa Barat 46213), (10) Dinas Cipta Karya, Kebersihan dan Tata Ruang Pemerintah Kabupaten Ciamis (JL. R.A.A. Kusumahsubrata, No. 7, Kertasari, Kec. Ciamis, Kabupaten Ciamis, Jawa Barat 46213), (11) Badan Pelaksana Penyuluh Pertanian, Perikanan Dan Kehutanan Pemerintah Kabupaten Ciamis (JL. RAA. Kusumahsubrata, No. 16, Kertasari, 
Kec. Ciamis, Kabupaten Ciamis, Jawa Barat 46213), (12) Dinas Kebudayaan Dan Pariwisata Pemerintah Kabupaten Ciamis (JL. Mr. Iwa Kusumasumantri, No. 14, Kertasari, Kec. Ciamis, Kabupaten Ciamis, Jawa Barat 46213), (13) Perusahaan Daerah Air Minum (PDAM) Tirta Galuh (JL. Mr.Iwa Kusumasomantri, No. 16, Kertasari, Kec. Ciamis, Kabupaten Ciamis, Jawa Barat 46213), (14) Badan Pengelolaan Keuangan Daerah Kab. Ciamis (Jl. Drs. H. Soejoed No.5, Kertasari, Kec. Ciamis, Kabupaten Ciamis, Jawa Barat 46213), (15) Badan Perencanaan Pembangunan Daerah Pemerintah Kabupaten Ciamis (Jl. Stasiun No.18, Ciamis, Kec. Ciamis, Kabupaten Ciamis, Jawa Barat 46211), (16) BKDD (Badan Kepegawaian Daerah dan Diklat) (Jl. Bojonghuni No.7, Maleber, Kec. Ciamis, Kabupaten Ciamis, Jawa Barat 46214), dan (17) Kejaksaan Negeri - Ciamis (JL. Siliwangi, No. 95, Maleber, Kec. Ciamis, Kabupaten Ciamis, Jawa Barat 46214).

Lingkup kedua adalah lingkup kecamatan. Setelah kebutuhan pendistribusian di daerah kota Ciamis selesai, selanjutnya pendistribusian dilakukan ke kecamatan yang ada di Ciamis yang terdiri dari: Kecamatan Banjarsari, Kecamatan Baregbeg, Kecamatan Ciamis, Kecamatan Cidolog, Kecamatan Cihaurbeuti, Kecamatan Cijeungjing, Kecamatan Cikoneng, Kecamatan Cimaragas, Kecamatan Cipaku,
Kecamatan Cisaga, Kecamatan Jatinagara, Kecamatan Kawali, Kecamatan Lakbok, Kecamatan Lumbung, Kecamatan Pamarican, Kecamatan Panawangan, Kecamatan Panjalu, Kecamatan Panumbangan, Kecamatan Purwadadi, Kecamatan Rajadesa, Kecamatan Rancah, Kecamatan Sadananya, Kecamatan Sindangkasih, Kecamatan Sukadana, Kecamatan Sukamantri, Kecamatan Tambaksari, Kecamatan Banjaranyar.

Jumlah yang didistribusikan dibagi secara rata berdasarkan kebutuhan tiap daerah hal ini dilakukan agar pendistribusian merata. Untuk pendistribusian Tabloid Dinamis dilaksanakan secara langsung atau dapat dikatakan tidak memakai kendaraan pengangkut pendistribusian dilakukan dengan menggunakan mobil kantor Setda Kabupaten Ciamis. Tak ada evaluasi dari pengelolaan Tabloid Dinamis ini hanya saja setiap keluhan dan permasalahan yang didapat pada proses pengelolaan langsung disampaikan ke Wakil Pimpinan Redaksi yaitu Kasubag publikasi dan dokumentasi yang paling dekat dengan para pegawai lain dan setelahnya akan disampaikan ke pemimpin redaksi yaitu Kabag Humas.

\section{SIMPULAN}

Berdasarkan hasil pengamatan dan pembahasan yang telah dipaparkan penulis, 
maka dapat diambil beberapa kesimpulan yang merupakan inti dari tahapan-tahapan yang dilakukan dalam "Pembuatan Tabloid Dinamis oleh Humas Setda (Sekretariat Daerah) Kabupaten Ciamis yaitu: (1) pada tahap pra produksi Tabloid Dinamis meliputi perencanaan isi dan rubrikasi, pengumpukan informasi Tabloid Dinamis dan proses desain dan layout, (2) pada tahapan produksi Tabloid Dinamis meliputi frequency, quantity dan proses percetakan Tabloid Dinamis, dan (3) tahapan pasca produksi Tabloid Dinamis meliputi proses peliputan dan evaluasi.

Saran yang dapat penulis sampaikan sebagai bahan masukan bagi perbaikan pengelolaan Tabloid Dinamis yang dikelola oleh humas Setda Kabupaten Ciamis antara lain: (1) seharusnya agar lebih efektif sebaiknya memanfaatkan keadaan yang ada seperti pada saat peliputan acara pasti ada protokoler atau staf dari bagian lain yang hadir, lebih baik bekerjasama dengan staf lain untuk proses peliputan sehingga berita tetap didapatkan meskipun tim peliput tidak ada di lokasi yang sama, (2) perlu dibuatnya rubrikasi yang pasti dan baik agar informasi yang disajikan dapat terpilah dan pembaca dapat mencerna dan mencari informasi dengan lebih baik, (3) perlu adanya manajemen waktu agar frequency dari penerbitan tidak lancar, (4) agar pendistribusian tidak terlambat alangkah lebih baik jika proses pendistribusian juga melibatkan pihak jasa pengiriman barang seperti pos atau yang lainnya agar pengiriman tidak terlalu lama, dan (5) sebaiknya ada proses evaluasi yang resmi agar dapat menjadi tolak ukur dan dapat membuat Tabloid Dinamis yang lebih baik lagi.

\section{DAFTAR PUSTAKA}

Bappeda. (2015). Profile ciamis, [rar (pdf)] (http://ciamiskab.go.id/profile/ (diakses tanggal 10 April 2017).

Damayanti, T. \& Perbawasari, S. (2013). Persepsi mahasiswa tentang posisi strategis profesi public relations. Jurnal Kajian Komunikasi, 1 (1), 69-82.

Effendy, O. U. (2006). Hubungan masyarakat: suatu studi komunikologis. Bandung: Remaja Rosda Karya.

Hadiman, I. (2008). Inhouse magazine. Jakarta: GAUL Publishing.

Jefkins, F. (2004). Public relations. Jakarta: Erlangga

Memet, H. (2017). Personal Interview.

Rakhmat, J. (2009). Metode penelitian komunikasi. Bandung: Remaja Rosdakarya

Rizkahaj, H. P. \& Wahyuni, I. I. (2017). Analisis promotion mix puspa iptek sundial kota baru parahyangan. Jurnal PRofesi Humas, 2 (1), 45-56.

Ruslan, R. (2012). Manajemen public relations dan media komunikasi: konsepsi dan aplikasi. Jakarta: RajaGrafindo Persada.

Ruslan, R. (2013). Kiat dan strategi kampanye public relations. Jakarta: RajaGrafindo. Persada.

Siregar, A. (2004). Bagaimana mengelola Media korporasi organisasi. Yogyakarta: Kanisius. 
Soemirat, S \& Ardianto, E. (2012). Dasardasar public relations. Bandung: Remaja Rosdakarya.

Susanto, E. H. (2013). Undang-undang keterbukaan informasi publik dan penyelenggaraan pemerintahan. Jurnal
Komunikator. 5 (1), 53-58.

Yulianita. N. (2012). Dasar-dasar public relations. Bandung: Pusat penerbitan universitas lembaga penelitian dan pengabdian kepada masyarakat Universitas Islam Bandung (P2U-LPPM UNISBA). 